\title{
Researchers' Expectations Regarding the Online Presence of Academic Libraries
}

\section{Anna Mierzecka, Małgorzata Kisilowska, and Andrius Suminas}

The article reports the results of a survey conducted among the Polish and Lithuanian academics concerning their information needs and expectations regarding academic library websites. The survey was realized using the technique of Computer-Assisted Web Interviewing (CAWI) on a group of scholars representing sciences and humanities or social sciences and was preceded by desk research consisting of literature review and analysis. Quantitative analysis was carried out on the data provided by 460 respondents. Its findings are discussed in light of earlier research reports. Regardless of the users' research specialty, accessibility of online resources was revealed as the most important element of an academic library website, although information concerning the traditional or offline function of the library was also highly ranked. Minor differences in information needs were found depending on the age and nationality of the respondents. Access to online sources was revealed as the prevailing information need among the scholars. Moreover, differences in the information behaviors of the scientists and the humanists, widely discussed in literature, prove insignificant with regard to the expectations concerning the online presence of academic libraries. This could result from the development of digital humanities and the new standards imposed on the researchers within the humanities and social sciences, related to the evaluation of academic output performed by the government agencies in both countries. Digital presence of academic libraries still poses challenges, requiring observation of user information behaviors and a redefinition of the librarian's duties.

\section{Introduction}

For centuries, university libraries have constituted an essential part of academic life and science communication; and, while their role in the dissemination of research has not changed significantly over time, the tools that are used for that purpose certainly has. Among such tools, a prominent role is played by academic library websites providing the users with the opportunity for information literacy training as well as access to

Anna Mierzecka, Małgorzata Kisilowska, and Andrius Suminas are Assistant Professors at Faculty of Journalism, Information and Book Studies at the University of Warsaw, and Andrius Suminas is also Associated Professor at Faculty of Communication at Vilnius University; e-mail: anna.mierzecka@uw.edu.pl, emka@uw.edu.pl,andrius.suminas@kf.vu.lt. @2017 Anna Mierzecka, Małgorzata Kisilowska, and Andrius Suminas, Attribution-NonCommercial (http://creativecommons.org/licenses/by-nc/4.0/) CC BY-NC. 
online public access catalogues (OPACs) and the library's own and mediated online collections. Alongside the changes in the information behaviors of scholars representing various academic disciplines, there arises the issue of their perceptions and expectations concerning the online services of libraries. The following section of the article presents an overview of literature including both a broader perspective of the scholars' information behaviors and a discussion of the evolution of academic library websites. The authors then proceed to discuss the findings of a survey conducted in January and February of 2016 among the scholars from two universities (one in Poland and one in Lithuania), concerning their needs with regard to the content of the academic library website. The article concludes with remarks on current trends in planning online library services.

\section{Theoretical Background}

Differences in information behaviors and preferences found among the humanists and social scientists, contrasted with those typical of pure, life, engineering, and other sciences, have been discussed by several studies. ${ }^{1}$ Scientists and engineers are generally reported to focus heavily on electronic resources, particularly journal articles, web-based resources, and databases, because of their convenience, speed, and interactivity. ${ }^{2}$ They are also viewed as more independent and self-reliant, preferring individual searching (including the simplest "trial and error" method) to formalized, more complicated, and time-consuming ways. ${ }^{3}$ Humanists tend to prefer reference sources, dissertations, and articles, ${ }^{4}$ but their attitudes toward electronic resources and their levels of digital skills evolve in time, following the increased accessibility of specific resources dedicated to their research. ${ }^{5}$ Humanities and social sciences scholars are also more likely to seek the librarian's assistance in their searches. ${ }^{6}$ Haglund \& Olsson report further differences between the researchers representing humanities and social sciences vs. pure sciences found in the use of various media types (books vs. journal articles), the age of information (new vs. archival), and the preferred use of libraries (onsite or online). ${ }^{7}$ However, already over a decade ago, Talja and Maula suggested that surveying and discussing information behaviors of the humanists viewed as a homogeneous category was no longer reasonable, as methods and ways of searching for information differ among particular disciplines, or even specialties, within the humanities; therefore, their representatives should be analyzed separately. ${ }^{8}$ Regardless of their disciplinary background, researchers value highly academic databases, Google services, and academic library catalogues. They refer to library collections of journal articles relatively often ${ }^{9}$ and view remote access to information resources as the main benefit of digital technologies in the research practice. ${ }^{10}$ Simple searching prevails in general, while the advanced searches are realized mostly via academic library resources or private digital collections. ${ }^{11}$

Besides surveying discipline-oriented information-seeking behaviors, subject literature also notes or implies the existence of further differences among the users (for instance, with regard to their age, level of digital competency, and/or habits). More or less obvious differences between the younger and older users - for instance, doctoral students and faculty members - have been found in the choice of the initial point of access to scientific information. The former group is more likely to start with general search engines, while the latter chooses library resources. ${ }^{12}$ Often, young researchers do not have a clear searching strategy, which is both the reason and the effect of their preferred use of Google or other general search engines. ${ }^{13}$

Apart from the scholarship on the general information behaviors of the researchers, a rich body of literature is devoted specifically to their use of academic libraries. The LARIAH project, which investigates the use of online digital resources in the humanities, has discovered that the humanists and social scientists view the university library website as a resource of key importance itself and a gateway to further resources. ${ }^{14}$ 
Notably, researchers generally view their librarians as qualified in information selection, organization, and dissemination ${ }^{15}$ and recognize their fundamental function as an intermediary to the world of information. However, as an effect of changes resulting from the developments in the information and communications technologies (ICT), most researchers hardly visit the libraries in person and prefer to use the online rather than onsite services. ${ }^{16}$

In the scholarly discussions of the researchers' current information and communication needs, traditional functions of libraries continue to be mentioned, but they have evolved and adapted to the present day. For instance, the respondents often emphasize the significance of interpersonal communication in the process of research, and libraries address this particular need in more than one way: as institutions offering a profiled research communication networks and platforms ${ }^{17}$ or by offering personal assistance in searching for specialized e-resources. ${ }^{18}$ Sources also report the need for library services to be effectively promoted among potential users, with communication tailored appropriately to the needs of different types of users. ${ }^{19}$ The humanists are particularly discouraged by unfriendly interfaces, time-consuming library training, navigation or search problems, incomplete resources and their poor quality, and the lack of older materials. ${ }^{20}$ Haglund and Olsson emphasize the need for simple, consistent, and personalized online services, ${ }^{21}$ while the U.S. Institute of Museum and Library Services project stresses the researchers' convenience as a determinant of successful information searching and retrieval, ${ }^{22}$ defining convenience as the knowledge of sources, perceived ease of use (speed and ease of access), full access to resources (full-texts), and physical proximity. Relevance to the pursued academic task is a significant factor influencing the usage of library websites: Kim notes the importance of a simple and logical design, the convenience of use, remote access to library services, competencies of the librarians, the website's customization, and easy browsing. ${ }^{23}$

There is also a reported need for the library searching services to be integrated within the departmental websites, as a part of the so-called personalized researchers' workbench, migrated into the users' environment and workflow. ${ }^{24}$ The latter should include also assistance with citation management software, archiving, and repositories, as well as the management of research data. ${ }^{25}$

\section{Research Questions}

The academic library website is the first place of contact with the library for those who want to use its digital services, but those who are interested in more traditional services often use it as well. While developments in technology have resulted in exciting opportunities for library websites (for instance, allowing consolidation of all potentially interesting content in one place), librarians still have to choose which information or services are to be given greater exposure, and their choices must be based on the recognition of the information needs of users. This issue was identified and addressed in a survey aimed at examining expectations about the library website found among academics. Taking into account the complex variables influencing information needs in general, conducted research included those identified at the stage of desk research as potentially influencing the academics' information needs. Consequently, the following research questions were formulated:

RQ1. What elements of academic library websites are perceived by scholars as crucial or important with regard to their information needs?

RQ2. Do opinions on the role of academic library websites differ between scientists and social/humanities researchers?

RQ3. Are there any differences in the perceptions of academic library websites related to the age of the scholars? 
RQ4. Do perceptions of academic library websites differ between scholars from various academic communities?

\section{Research Methodology and Framework Study Design and Method}

The survey was realized using the technique of Computer-Assisted Web Interviewing (CAWI) in January and February 2016. The questionnaire consisted of two parts: open- and close-ended questions, and gathered basic demographic data (age, sex, research areas). Open-ended questions addressed the respondents' individual preferences concerning the most important academic library website elements (a maximum of 3 to be specified) and the type of social media used while looking for information about the library (if applicable).

The close-ended question listed 20 library website elements (see figure 1) directly related to its functions as defined by Sapa, ${ }^{26}$ further developed by Mierzecka and Suminas ${ }^{27}$ in a study of the information needs of students. The proposed list is necessarily limited to the core and/or most popular academic library websites content elements and does not claim to correspond fully to an academic library website structure. While the proposed list largely reflects the actual expectations listed by the respondents in the answers to the first open-ended question, as shown below, one must always remain aware of the unpredictable or unexpected user needs.

Scholars invited to participate in the survey represented two universities and two countries: University of Warsaw (UW, Poland), and Vilnius University (VU, Lithuania), two of the largest academic institutions in the respective countries. The invitation was sent by e-mail (containing a link to the survey) to all academics of the faculties in sciences, humanities, or social sciences whose e-mail addresses were accessible through the universities' contact lists. The number of academic staff at each university differs (UW: 3,223, UV: 1,329); but this was not found to be an obstacle, as the results for all questions were calculated as an average from the total number of the received answers. The total number of e-mails sent to the UW representatives was 2,290 (997 to scientists, 1,293 to humanities and social sciences scholars). In Lithuania, 1,146 invitations were sent out ( 574 to scientists, 572 to humanities and social sciences scholars).

\section{Findings}

A total of 320 filled surveys were received in Poland (response rate 13.9\%) and 140 in Lithuania (response rate $12.2 \%$ ).

The demographic characteristics of the Polish (PL) and Lithuanian (LT) respondents are presented below in table $1 .^{28}$

\begin{tabular}{|c|c|c|c|c|c|c|c|c|c|}
\hline & Demog & aphic & racte & $\begin{array}{r}T A \\
\operatorname{cs~of~} t\end{array}$ & $\begin{array}{l}\text { E } 1 \\
\text { Polish }\end{array}$ & Lith & iian $\mathrm{F}$ & onden & \\
\hline$\%$ & $\mathbf{G e}$ & Ider & & & Age & & & Rese: & ch Area \\
\hline & Women & Men & $25-35$ & $36-45$ & $46-55$ & $56-65$ & $65+$ & Science & $\begin{array}{c}\text { Social/ } \\
\text { Humanities }\end{array}$ \\
\hline $\begin{array}{l}\text { PL } \\
(n=320)\end{array}$ & $\begin{array}{c}168 \\
(52.5 \%)\end{array}$ & $\begin{array}{c}152 \\
(47.5 \%)\end{array}$ & $\begin{array}{c}75 \\
(23.4 \%)\end{array}$ & $\begin{array}{c}129 \\
(40.3 \%)\end{array}$ & $\begin{array}{c}71 \\
(22.2 \%)\end{array}$ & $\begin{array}{c}39 \\
(12.2 \%)\end{array}$ & $\begin{array}{c}6 \\
(1.9 \%)\end{array}$ & $\begin{array}{c}99 \\
(30.9 \%)\end{array}$ & $\begin{array}{c}221 \\
(69.1 \%)\end{array}$ \\
\hline $\begin{array}{l}\text { LT } \\
(n=140)\end{array}$ & $\begin{array}{c}58 \\
(41.4 \%)\end{array}$ & $\begin{array}{c}82 \\
(58.6 \%)\end{array}$ & $\begin{array}{c}49 \\
(35 \%)\end{array}$ & $\begin{array}{c}43 \\
(30.7 \%)\end{array}$ & $\begin{array}{c}26 \\
(18.5 \%)\end{array}$ & $\begin{array}{c}18 \\
(12.9 \%)\end{array}$ & $\begin{array}{c}4 \\
(2.9 \%)\end{array}$ & $\begin{array}{c}74 \\
(52.8 \%)\end{array}$ & $\begin{array}{c}66 \\
(47.2 \%)\end{array}$ \\
\hline $\begin{array}{l}\text { Total } \\
(n=460)\end{array}$ & $\begin{array}{c}226 \\
(49.1 \%)\end{array}$ & $\begin{array}{c}234 \\
(50.2 \%)\end{array}$ & $\begin{array}{c}124 \\
(26.9 \%)\end{array}$ & $\begin{array}{c}172 \\
(37.4 \%)\end{array}$ & $\begin{array}{c}97 \\
(21.1 \%)\end{array}$ & $\begin{array}{c}57 \\
(12.4 \%)\end{array}$ & $\begin{array}{c}10 \\
(2.2 \%)\end{array}$ & $\begin{array}{c}173 \\
(37.6 \%)\end{array}$ & $\begin{array}{c}287 \\
(63.4 \%)\end{array}$ \\
\hline
\end{tabular}


To provide a clear discussion of the collected data, study findings will be presented in the following section of the article.

$R Q 1$. What elements of academic library websites are perceived by the scholars as crucial or important with regard to their information needs?

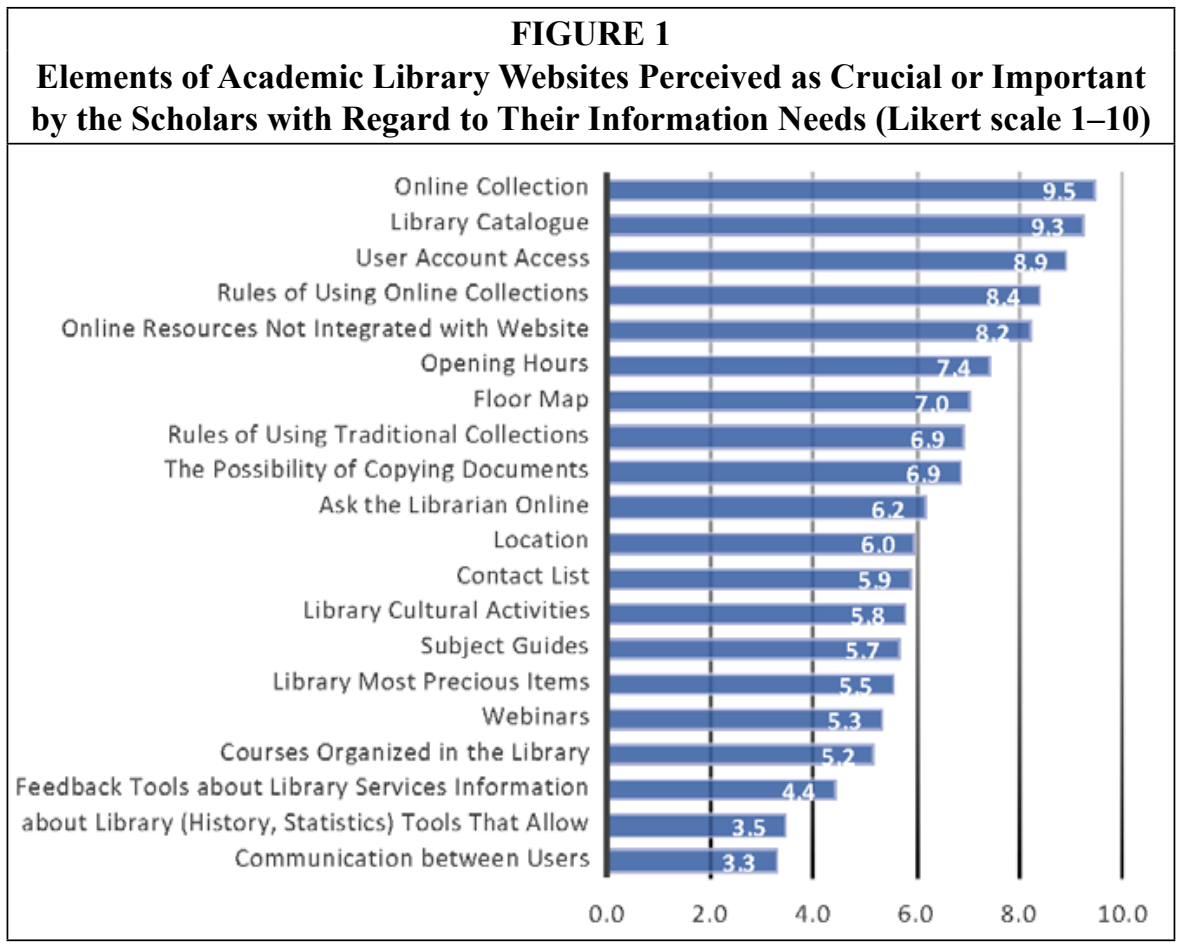

Figure 1 presents the respondents' perceptions concerning the most important elements of the academic library websites. The results were obtained from the close-ended question, which included a list of elements provided by the authors of the survey accompanied by a 1-10 point scale, where $1=$ the least and $10=$ the most important element. The findings generally support the conclusions drawn by the authors of the earlier studies, presented in the literature overview section of the present article: online resources of the academic library receive the highest degree of interest from the scholars in both Polish and Lithuanian academic communities (9.5 point). Providing access to online collections is confirmed as the main role of the academic library website, although, notably, the instruction on how to use such collections (referred to as Rules of using online collections in figure 1) was also assessed as very important (8.4). These are followed by the library catalogue (9.3), providing information about both traditional collections and electronic subscriptions of books and journals. Importantly, all content elements that scored $>8$ points, including the library catalogue, are related to the digital services or resources.

The remarkably high rank of the online resources not integrated with the website ${ }^{29}(8.2)$ must not be ignored by the librarians: their roles as procurers and curators of electronic resources cannot be limited to library resources only. Librarians are to act as gatekeepers of all other useful, verified, and valuable Internet scholarly resources - this particular indication reflects also the findings of the earlier studies. ${ }^{30}$ 
Another consistent cluster of answers can be distinguished from the respondents' choices concerning the general usage of traditional library collections onsite. It includes: opening hours, floor maps, rules of using traditional collections, the possibility of copying documents (between 7.4 and 6.9 points).

The remaining answers (score 6.2 and below), including various library activities, tools, or collections, was met with less interest from the academics, with the library history and communication tools earning the lowest ranks.

The above results can be compared to the indications offered by the respondents answering the first open-ended question. As mentioned before, its goal was to motivate the respondents to think independently and decide what they actually expect entering an academic library website. This was supported by the structure of the questionnaire, intentionally designed to hide the list of potential academic library website elements included in the last question.

Since each respondent could suggest no more than 3 elements, the total number of the results does not correspond exactly to the total number of 460 surveys collected: we gathered 974 indications $\left(n_{\mathrm{PL}}=685 ; \mathrm{n}_{\mathrm{LT}}=307\right)$ (see figure 2).

The first three elements correspond to those presented in figure 1: online collection (35\% of indications), library catalogue (28\% of indications), user account access ( $9 \%$ of indications) - and the domination of the first two is significant. An academic library website performs primarily the role of a gate to resources, both the digital and analogue ones. However, here end the similarities between the answers to the open- and close-ended questions. In figure 2, the fourth rank belongs to the opening hours (7\% of indications), while in figure 1 online resources not integrated with the website and rules of

\begin{tabular}{|r|r|r|r|} 
& FIGURE 2 \\
\hline Number of the Scholars' Individual Indications Concerning the Important \\
Elements of the Academic Library Website (n=974)
\end{tabular}


using online collections occupy the fourth position. In figure 2, the latter elements can be found on the 8th and 10th positions respectively.

A few answers failed to meet the intention of the question. A group of our respondents (7\% of indications) mentioned advanced search options: in other words, citation search options, multiformat search options, and the like. Although search options are in fact a part of the online collections, library catalogue, or the website navigation tool, these answers are presented separately to highlight better the importance assigned by the academics to the tools supporting a precise formulation of their information needs. The respondents mentioned also another element not listed in the close-ended question, namely, new acquisitions in the library. It seems that the academics would like to see this information displayed on the academic library website, although many are interested only in the acquisitions related to their area of research. Another suggestion - clear website design ( $2 \%$ of indications) - is rather an attribute than a separate element of an academic library website; nonetheless, it seems to be a necessary attribute and one requiring improvement, as it was mentioned by quite a number of the respondents relying on their navigation experience so far.

The interest in online resources not integrated with the website, even if mentioned only by 2 percent of indications, is also noteworthy: some researchers still perceive a library website as a gate to valuable resources available on the Internet. Other elements mentioned by the users amounted to only 1 percent or less of all indications (see figure 2).

To increase the knowledge of academics' needs related to the digital presence of the library, one more question was asked: Do you use social media to obtain information about academic libraries? ${ }^{31}$ A total of 46 positive answers were received (29 PL, 17 LT), among which Facebook was indicated by 34 respondents, Twitter by 3, Google + by 2; other respondents mentioned media that cannot be considered a source of information about library activity (LinkedIn, ResearchGate, and other similar media). These results reveal a very low level of use of digital channels other than the library website itself to obtain information about the library activity.

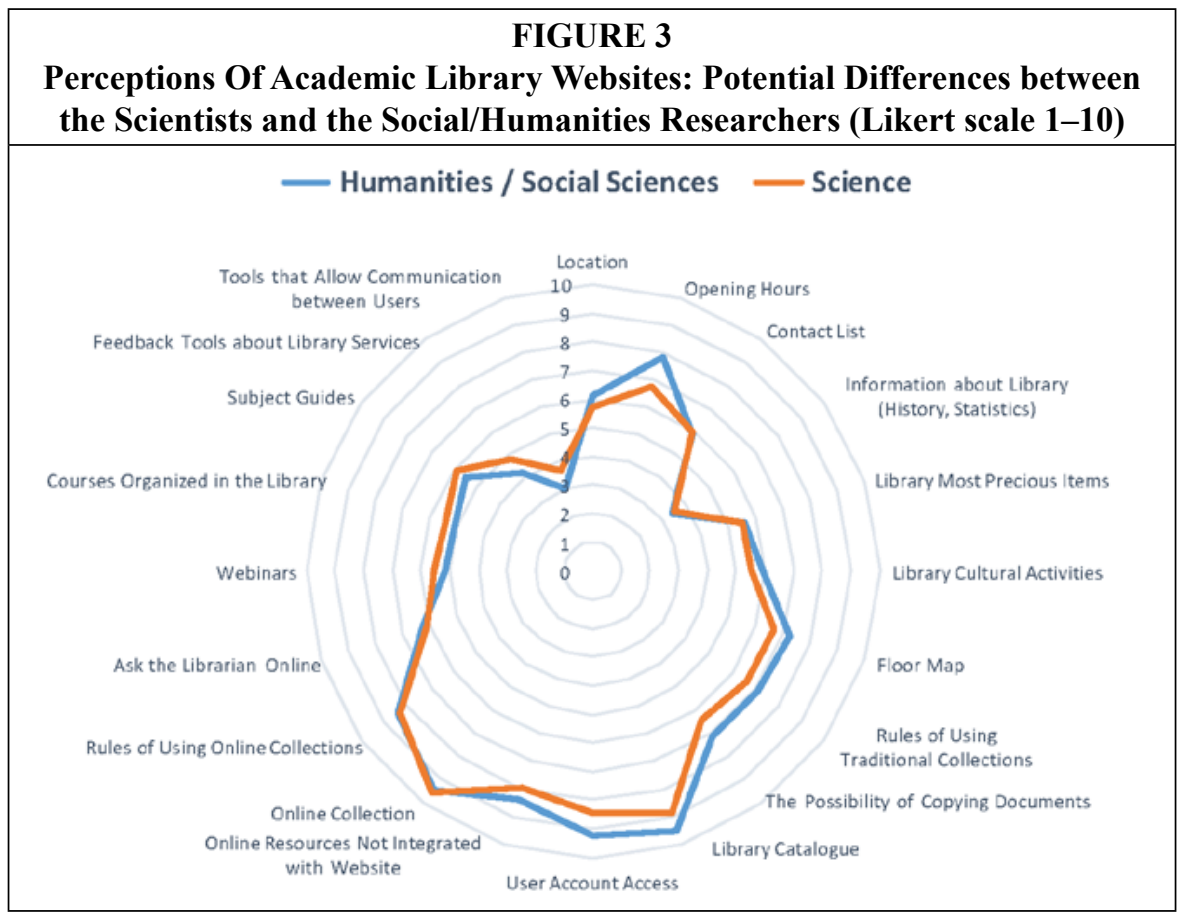


RQ2: Do opinions on the role of academic library websites differ between the scientists and the social/humanities researchers?

Studies in the literature suggested the existence of serious discrepancies between the humanities/social academics and scientists. ${ }^{32}$ In spite of that, the results of the conducted survey do not differ substantially between those two groups. Apart from general tendencies observed in the academics as a whole, it was found that the humanities/social science scholars are slightly more interested in the academic library website elements that concern access to traditional collections, like: opening hours (the major difference: social/humanities representatives $[\mathrm{So} / \mathrm{H}], 7.9$; science representatives [S], 6.7), floor maps $(\mathrm{So} / \mathrm{H}, 7.2 ; \mathrm{S}, 6.6)$, rules of using traditional collections $(\mathrm{So} / \mathrm{H}$, $7.1 ; \mathrm{S}, 6.6)$, the possibility of copying documents $(\mathrm{So} / \mathrm{H}, 7.1 ; \mathrm{S}, 6.4)$, and so on. The high ranks of library catalogue $(\mathrm{So} / \mathrm{H}, 9.5 ; \mathrm{S}, 8.8)$ and user account $(\mathrm{So} / \mathrm{H}, 9.2 ; \mathrm{S}, 8.5)$ awarded by this group of respondents can also be explained by their inevitable relation to the usage of traditional collections. Meanwhile, the scientists proved to be slightly more interested in electronic communication using the tools offered by the library $(\mathrm{So} / \mathrm{H}, 3.0 ; \mathrm{S}$, 3.7), although in general they also do not consider these website elements to be of real importance. Both the humanists and the scientists are primarily interested in access to online resources $(\mathrm{So} / \mathrm{H}, 9.5 ; \mathrm{S}, 9.6)$, which seems to confirm the results of previous studies: ${ }^{33}$ remote access to information resources is perceived as the main benefit of digital technologies in research practice regardless of the research area. It is even more noteworthy in the light of the fact that both university libraries used in the study subscribe to more e-journals than books, while many studies confirm that humanities and social sciences researchers prefer books. ${ }^{34}$ Another surprising result concerns the low interest in ask the librarian option $(\mathrm{So} / \mathrm{H}, 6.2 ; \mathrm{S}, 6.1)$, especially among the humanities and social sciences researchers, who tend to use the librarian's assistance more frequently in their searches. ${ }^{35}$ However, as the online consultation option has been only recently introduced to both the UW and VU libraries, the respondents may simply not be used to such service. Another possible explanation is that a chat (in the form of a written request) is a less convenient method of communication, or - finally - that there are cultural differences in the preferred forms of contacting librarians between the Lithuanian and Polish vs. Western researchers.

RQ3: Are there any differences in the perceptions of academic library websites related to the age of the scholars?

As indicated by figure 4 , there are no significant differences among the academics in the 36-65 age group, which includes the majority of our respondents -70.8 percent $(\mathrm{n}=326)$. However, such differences can be found in the choices made by the youngest group: $25-35$ ( $n=124 ; 26.9 \%$ of respondents). The youngest users were interested in the opening hours and floor map more than the other age groups (see figure 1, table 2, appendix A), and these two results suggest that the youngest group is more likely to visit the library in person and not only access its digital resources. The latter finding also seems to contradict the results of other studies, presenting young researchers as those using digital resources far more often than traditional collections. ${ }^{36}$ Neither the survey method used in the presented study nor the response rate allow a resolution of this problem with absolute certainty. However, young researchers are probably quite familiar with web design principles and information architecture; as such, they can easily indicate crucial elements of an academic library website, even if they are not personally interested. Young researchers are also slightly more interested in the library's educational offerings (see figure 1, table 2, appendix A), such as webinars, courses, e-learning materials, subject guides, and the like. This may be related to the early stage of their academic career as well as their preferences concerning the online, easily accessible education. 


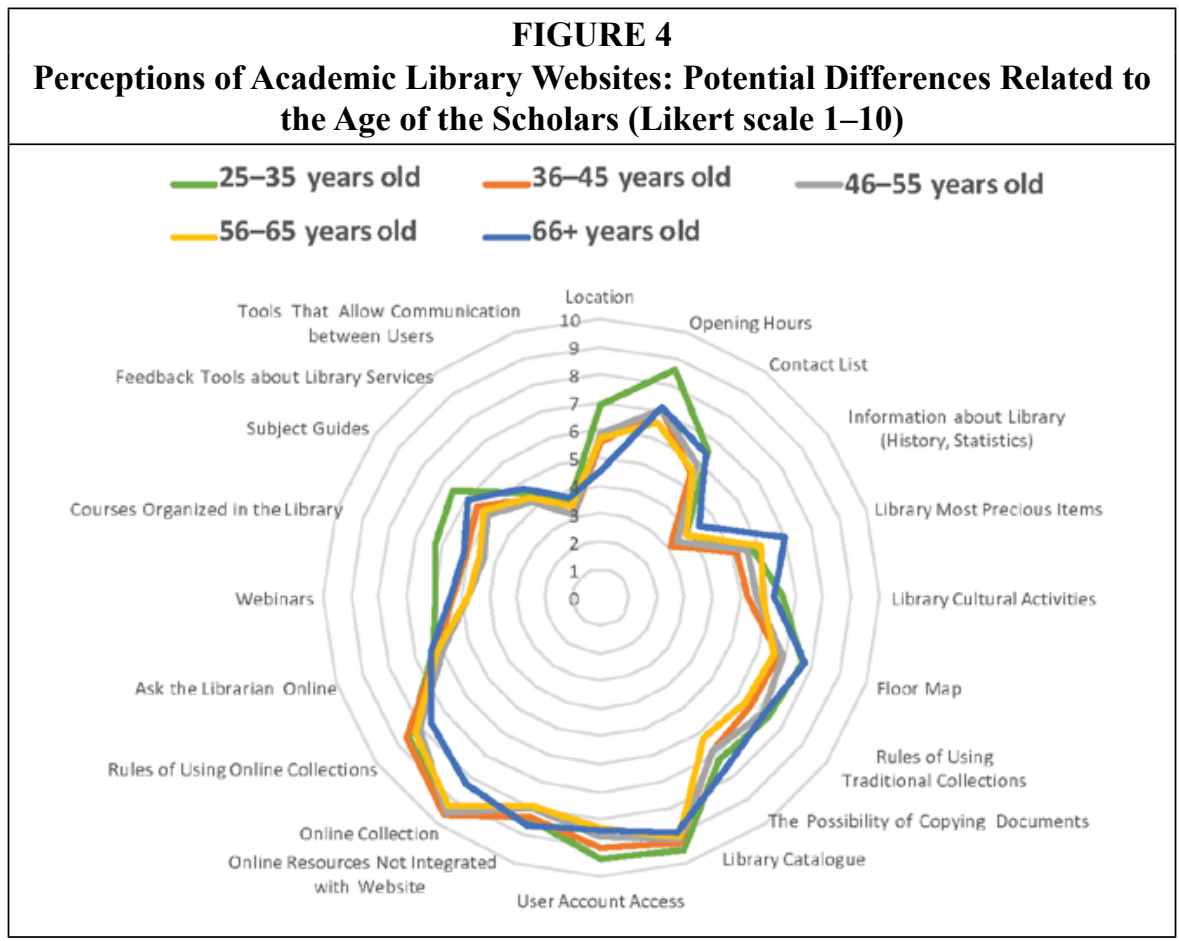

Online collections are preferred by all age groups except 66+. The latter, in contrast to the other respondent groups, more often indicated library treasures and the floor map as important academic library website elements and was less interested in various forms of library trainings (see figure 1, table 2, appendix A). This result supports the findings of the earlier studies, where older people (not only scientists) were revealed as users more reluctant to digital technologies. The older generation also pays more attention to the library's function of preserving cultural heritage, which seems to be underestimated by the youth. However, it must be emphasized that only 10 academics of that age (2.1\%) answered the survey. Presumably these researchers make a smaller group of active academics, and they also less willingly participate in e-mail surveys.

RQ4: Do perceptions of academic library websites differ between the scholars from various academic communities?

The research question concerning potential differences in the assessment of academic library website elements between the representatives of Lithuanian and Polish universities was an important part of our study. Answers reveal the extent to which individual experiences with a particular library/academic society influence their information needs and preferences, and (as a result) their assessment of academic library websites in general. Individual experiences influence also the range of potential generalization of the survey results to the academic society as a whole. Here, no differences were found regarding the highest-ranking elements (online collection, library catalogue, opening hours); the academics seem to be unanimous in this regard. Other opinions were more diversified, in particular the ones related to the library's educational offerings: webinars (UW, 5.1; VU, 5.8), courses organized in the library (UW, 4.9; VU, 5.9), and materials for self-education, such as subject guides (UW, 5.3; VU, 6.5). Three possible explanations of these differences can be proposed: 


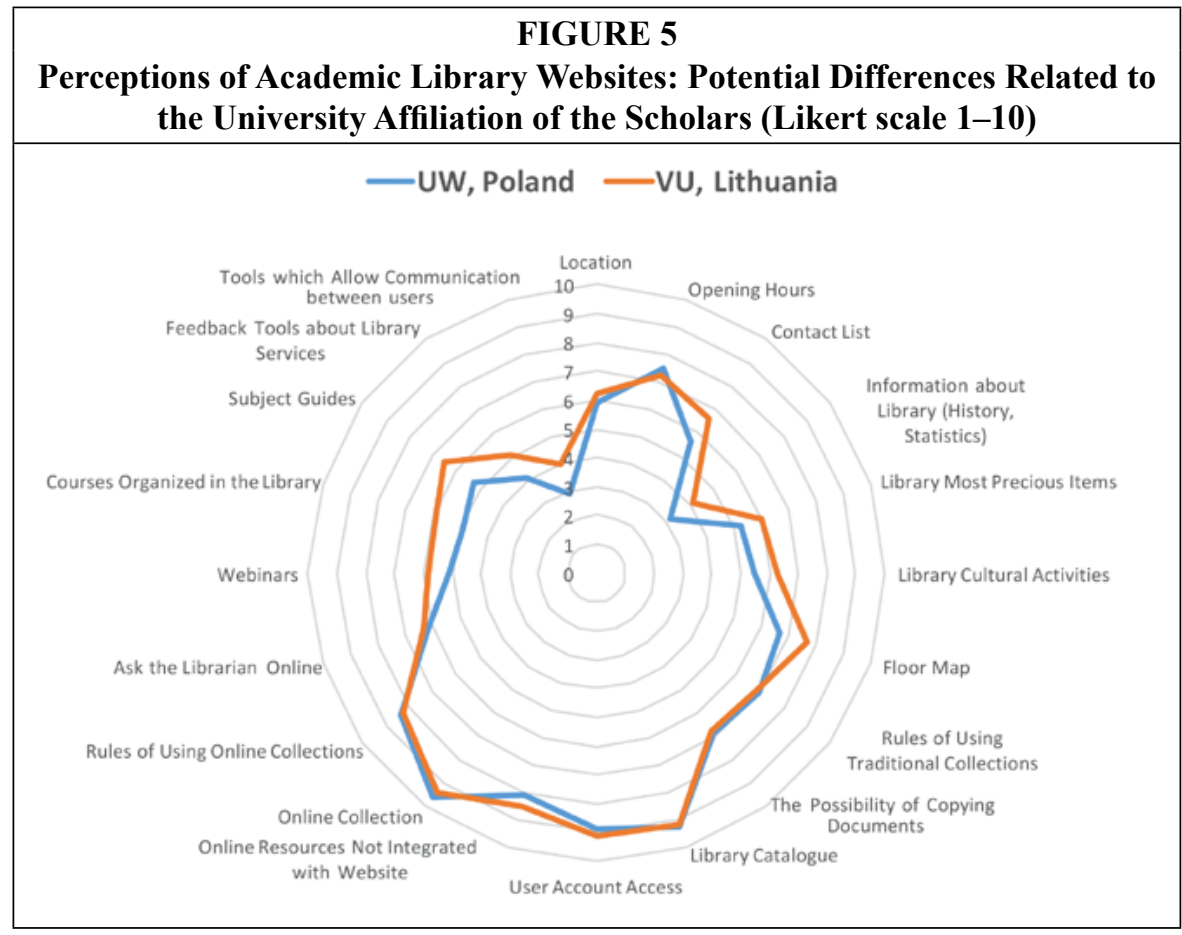

1. Lithuanian respondents were younger than the Polish ones (35\% vs. $23 \%$ of the group no older than 35) - as already mentioned, young researchers proved to be the group exhibiting the greatest degree of interest in the educational offerings (see figure 4).

2. The offerings of Lithuanian libraries are more attractive than the Polish ones.

3. Lithuanian academics are in general more eager to improve their skills.

However, both the findings and their discussion presented above need further qualitative research to fully recognize the motives and reasons behind the attitudes and preferences of the scholars concerning academic library websites. The same can be said about the observed bigger interest in information about library, library most precious items, library cultural activities among the Lithuanians. Is it a result of their greater concern with the library as a cultural institution or, perhaps, of the library's more attractive presentation of its heritage and the offered cultural activities? Higher rank of the floor map is probably connected to the specific features of the library that the respondents are used to, just as their evaluation of communication tools available at the library website.

\section{Discussion}

Studies in the literature implied the existence of serious discrepancies between the humanities/social academics and scientists. ${ }^{37}$ In spite of that, findings of the survey presented in detail in the previous section of the article led to a general conclusion that the academics' primary information needs concerning their libraries are in fact quite unified. Both groups prefer online to printed or manuscript resources and perceive librarians as guides and gatekeepers of all types of scholarly resources. Significantly, the needs of the humanists and social scientists have changed recently, as this group is now as much interested in the online tools and resources as the scientists. Their pref- 
erence for e-journals is also noteworthy. Attitudes in question have been observed in both academic communities, regardless the nationality, age, or any other demographic characteristics of our respondents.

These initially surprising similarities among the representatives of humanities, social sciences, and sciences, as well as the shared preference for online resources offered by the academic libraries, calls for an explanation. Two potential reasons and behavioral patterns of the scholars can be suggested here. The first is related to the emergence of the so-called digital humanities. There are several initiatives, such as DARIAH-EU, ${ }^{38}$ DESMM, ${ }^{39}$ ATHENA, $^{40}$ and many others, that actively support the introduction of digital tools into humanities research. Further, the ongoing development of web tools, applications, and resources such as language corpuses, digital libraries, and museums or raw data sets continues to influence both the research topics and methodologies and the skill levels of the scholars. Consequently, humanists have become increasingly better acquainted with the virtuality as a research environment, which entails also a preference for online rather than offline information-searching practices. As already suggested, all of us grew more used to online services in different spheres of life, including but not limited to banking, shopping, e-administration, and entertainment, and we appreciate the convenience and time-saving qualities of individual online searching. These widely observed habits and preferences may also influence the expectations of academics concerning library services and/or scholar communication in general. The researchers' first choice is to try to obtain the required information online using the home computer, whereas visiting the library building comes as a second choice.

The other reason for the preference for online to offline services may be traced to the state evaluation of institutions of higher education and output of their academic employees performed by the government agencies in the last decade both in Poland $(2012)^{41}$ and Lithuania (2010). As indicated by the current surveys of the information behaviors of the humanists in Poland ${ }^{42}$ as well as by the previously reported ones, ${ }^{43}$ researchers have become more deliberate with regard to journals they read and attempt to publish in. Such an attitude influences information-searching behaviors in general; information about journal titles, publishers, citations, or other indicators can be more easily found online. Journals available online have become an obvious choice, as easy access means better chances for being cited and consequently earning a higher rank in the evaluation process, both in the case of individuals and academic institutions.

The results did not confirm the need for a website's customization mentioned in literature, ${ }^{44}$ at least not in the case of particular academic library website elements -it seems that the website's layout should expose (and guarantee an easy access to) the same elements regardless of the research area of the users. However, field-related personalization is expected from the content of particular elements, including (for instance) new library acquisitions, digital collections, and the like.

The interest of the respondents is not limited to the online collections, as proven by the high ranks awarded to the elements supporting the traditional or offline library activities (that is, opening hours, floor map, and so on). These results reveal that the perception of the library's role does not confine it only to the status of the gatekeeper of digital resources.

Significantly low ranks awarded to all types of digital tools for communication between the library and its user (like ask the librarian, feedback tools, or social media channels) must be emphasized. Taking into account the need for the librarian's assistance proven by other studies, ${ }^{45}$ the potential of such tools still appears untapped. Thus, finding an effective digital medium of communication with the users appears as a challenge for the librarians. Perhaps following the successful examples of online communication channels used by banks or e-shops could be suggested as a step in 
the right direction, as these are also what shapes the experiences of the users and undoubtedly influences their expectations concerning the libraries.

\section{Limitations of the Study}

As in the case of many other projects, the primary limitation of the conducted study is its rather low response rate, which precludes general conclusions and syntheses. The survey invitations were sent to all officially listed researchers within the humanities/ social sciences and sciences at two universities, but the obtained sample amounts to 460 respondents. Although the results of research question 4 prove that the assessment of the importance of website elements is very similar among the representatives of both universities, and in many instances also confirms the results of others studies found in the subject literature, a bigger sample would provide a more solid foundation for a generalization of the results.

The quantitative character of the collected data may be viewed as another weakness of the conducted study, but also as a challenge for further research. Obtained results present a picture of the scholars' expectations concerning the elements of academic library websites; however, we still need a deeper knowledge of the motives and reasons for such state of things (that is, the exact status of the ask the librarian element, the youngest group's interest in the opening hours, and other aspects). There is a need for further research based on qualitative methodology that would also allow studying the seeking behavior of the respondents and the use of particular website elements. The wide array of search option systems available today, such as the World-Cat Local or the Summon discovery platforms, the "bento-style" design of the search results and other solutions ${ }^{46}$ should also be verified with regard to the satisfaction of the users.

\section{Conclusion}

The survey conducted for the purpose of the study asked about the content elements of academic library websites viewed by the scholars as important from the perspective of their information needs. The results revealed access to online sources as the prevailing information need of the investigated community, one of equal importance to both the scientists and the humanities/social scientists. The latter seem to have reached a similar level of interest in the use of digital resources to that of the scientists, which is quite a new perspective in the research of scholarly information behaviors. A positive attitude toward online resources was also observed among the older academics.

Both the literature review and the findings of the survey should be followed by a few recommendations for academic libraries. Since the researchers (including the hard or social scientists and humanists) require constantly improved and updated electronic resources adapted to their specific needs and research strategies, ${ }^{47}$ potential support should be offered in the form of dedicated tutorials or profiled assistance. Notably, academic libraries are perceived as procurers and curators of electronic resources, and the librarians are perceived as teachers, educators, navigators, research consultants, and procurement agents. ${ }^{48}$ Developing information services concerning different aspects of academic life (including the ongoing research, events, grants and shared resources, including lab equipment, data or full-text repositories, and expertise) is a new area of great potential mentioned by the respondents in the research by Haines et al. ${ }^{49}$ In general, libraries are expected to adapt to the specific work styles of particular user groups. This can be achieved by the users' participation in designing library websites or a broader implementation of library 2.0 functions, which seem to be underestimated so far. ${ }^{50}$

Despite the long history of website design and online services, the digital presence of academic libraries still poses challenges and requires permanent evaluation, observation of user information behaviors, and a redefinition of the librarian's duties. 


\section{APPENDIX A.}

\begin{tabular}{|c|c|c|c|c|c|c|c|c|c|}
\hline & etailed Des & ription & $\begin{array}{l}\text { TA } \\
\text { Res }\end{array}$ & $\begin{array}{l}\text { LE } 2 \\
\operatorname{arch}\end{array}$ & ata ( & ikert & cale & $-10)$ & \\
\hline Elements of & Researcl & Area & & & Age & & & University & Affiliation \\
\hline $\begin{array}{l}\text { Academic } \\
\text { Library Websites }\end{array}$ & $\begin{array}{c}\text { Social/ } \\
\text { Humanities }\end{array}$ & Science & $\begin{array}{c}25- \\
35\end{array}$ & $\begin{array}{c}36- \\
45\end{array}$ & $\begin{array}{c}46- \\
55\end{array}$ & $\begin{array}{c}56- \\
65\end{array}$ & $66+$ & $\begin{array}{c}\text { University } \\
\text { of } \\
\text { Warsaw }\end{array}$ & $\begin{array}{l}\text { Vilnius } \\
\text { University }\end{array}$ \\
\hline Location & 6.2 & 5.7 & 6.9 & 5.5 & 5.9 & 5.8 & 4.5 & 5.9 & 6.2 \\
\hline Opening Hours & 7.9 & 6.7 & 8.6 & 7.1 & 7.1 & 6.6 & 7.2 & 7.5 & 7.2 \\
\hline Contact List & 5.9 & 6.0 & 6.5 & 5.5 & 5.9 & 5.6 & 6.4 & 5.6 & 6.6 \\
\hline $\begin{array}{l}\text { Information about } \\
\text { Library (History, } \\
\text { Statistics) }\end{array}$ & 3.4 & 3.5 & 3.8 & 3.1 & 3.4 & 3.8 & 4.4 & 3.2 & 4.1 \\
\hline $\begin{array}{l}\text { Library Most } \\
\text { Precious Items }\end{array}$ & 5.6 & 5.5 & 5.7 & 5.1 & 5.6 & 6.0 & 7.0 & 5.3 & 6 \\
\hline $\begin{array}{l}\text { Library Cultural } \\
\text { Activities }\end{array}$ & 5.9 & 5.5 & 6.5 & 5.3 & 5.6 & 5.8 & 6.2 & 5.5 & 6.3 \\
\hline Floor Map & 7.2 & 6.6 & 7.6 & 6.8 & 6.9 & 6.6 & 7.7 & 6.7 & 7.7 \\
\hline $\begin{array}{l}\text { Rules of Using } \\
\text { Traditional } \\
\text { Collections } \\
\end{array}$ & 7.1 & 6.6 & 7.4 & 6.6 & 7.2 & 6.4 & 7.2 & 7 & 6.9 \\
\hline $\begin{array}{l}\text { The Possibility } \\
\text { of Copying } \\
\text { Documents }\end{array}$ & 7.1 & 6.4 & 7.2 & 6.8 & 6.8 & 6.2 & 7.6 & 6.9 & 6.8 \\
\hline Library Catalogue & 9.5 & 8.8 & 9.6 & 9.3 & 9.1 & 9.0 & 8.9 & 9.3 & 9.2 \\
\hline $\begin{array}{l}\text { User Account } \\
\text { Access }\end{array}$ & 9.2 & 8.5 & 9.4 & 9.0 & 8.6 & 8.3 & 8.4 & 8.9 & 9.1 \\
\hline $\begin{array}{l}\text { Online Resources } \\
\text { Not Integrated } \\
\text { With Website }\end{array}$ & 8.4 & 7.9 & 8.4 & 8.3 & 8.0 & 7.9 & 8.6 & 8.1 & 8.5 \\
\hline Online Collection & 9.5 & 9.6 & 9.5 & 9.6 & 9.5 & 9.3 & 8.3 & 9.6 & 9.4 \\
\hline $\begin{array}{l}\text { Rules of Using } \\
\text { Online Collections }\end{array}$ & 8.4 & 8.4 & 8.5 & 8.6 & 8.1 & 8.2 & 7.6 & 8.4 & 8.3 \\
\hline $\begin{array}{l}\text { Ask the Librarian } \\
\text { Online }\end{array}$ & 6.2 & 6.1 & 6.3 & 6.2 & 5.9 & 6.2 & 6.4 & 6.1 & 6.3 \\
\hline Webinars & 5.2 & 5.5 & 6.0 & 5.3 & 4.8 & 4.8 & 5.4 & 5.1 & 5.8 \\
\hline $\begin{array}{l}\text { Courses Organized } \\
\text { in the Library }\end{array}$ & 5.1 & 5.4 & 6.2 & 5.1 & 4.4 & 4.6 & 5.2 & 4.9 & 5.9 \\
\hline Subject Guides & 5.5 & 5.9 & 6.5 & 5.5 & 5.1 & 5.2 & 5.9 & 5.3 & 6.5 \\
\hline $\begin{array}{l}\text { Feedback Tools } \\
\text { about Library } \\
\text { Services }\end{array}$ & 4.2 & 4.8 & 4.6 & 4.4 & 4.3 & 4.4 & 4.8 & 4.1 & 5.1 \\
\hline $\begin{array}{l}\text { Tools That Allow } \\
\text { Communication } \\
\text { between Users }\end{array}$ & 3.0 & 3.7 & 3.5 & 3.1 & 3.1 & 3.5 & 3.8 & 2.9 & 4 \\
\hline
\end{tabular}




\section{APPENDIX B.}

\section{Survey}

The goal of the survey is to verify the most important functions of the academic library website as seen by the user.

- Q1. Please list three key elements (information or services) that you would like to see on the academic library website.

1.

2.

3.

- Q 2. Do you use social media to obtain information about academic libraries?

$\square \quad \mathrm{NO}$

$\square \quad$ YES

- Q3. Please list the social media used when looking for information about academic libraries (if applicable).

- Q4. Please assess how important to you are the following elements of an academic library website. (1-completely unimportant, 10-very important)

TABLE 3

Survey: Websites Elements

\begin{tabular}{|l|l|l|l|l|l|l|l|l|l|l|l|}
\hline & & $\mathbf{1}$ & $\mathbf{2}$ & $\mathbf{3}$ & $\mathbf{4}$ & $\mathbf{5}$ & $\mathbf{6}$ & $\mathbf{7}$ & $\mathbf{8}$ & $\mathbf{9}$ & $\mathbf{1 0}$ \\
\hline 1. & Location & & & & & & & & & & \\
\hline 2. & Opening Hours & & & & & & & & & & \\
\hline 3. & Contact List & & & & & & & & & & \\
\hline 4. & $\begin{array}{l}\text { Information about } \\
\text { Library (History, } \\
\text { Statistics) }\end{array}$ & & & & & & & & & & \\
\hline 5. & $\begin{array}{l}\text { Library Most } \\
\text { Precious Items }\end{array}$ & & & & & & & & & & \\
\hline 6. & $\begin{array}{l}\text { Library Cultural } \\
\text { Activities }\end{array}$ & & & & & & & & & & \\
\hline 7. & Floor Map & & & & & & & & & \\
\hline 8. & $\begin{array}{l}\text { Rules of Using } \\
\text { Traditional } \\
\text { Collections }\end{array}$ & & & & & & & & & & \\
\hline 9. & $\begin{array}{l}\text { The Possibility of } \\
\text { Copying Documents }\end{array}$ & & & & & & & & & & \\
\hline 10. & Library Catalogue & & & & & & & & & & \\
\hline 11. & User Account Access & & & & & & & & & & \\
\hline 12. & $\begin{array}{l}\text { Online Resources Not } \\
\text { Integrated with the } \\
\text { Website }\end{array}$ & & & & & & & & & & \\
\hline 13. & Online Collection & & & & & & & & & & \\
\hline 14. & $\begin{array}{l}\text { Rules of Using Online } \\
\text { Collections }\end{array}$ & & & & & & & & & & \\
\hline 15. & $\begin{array}{l}\text { Ask the Librarian } \\
\text { Online }\end{array}$ & & & & & & & & & & \\
\hline
\end{tabular}




\begin{tabular}{|c|c|c|c|c|c|c|c|c|c|c|c|}
\hline \multicolumn{12}{|c|}{$\begin{array}{c}\text { TABLE } 3 \\
\text { Survey: Websites Elements }\end{array}$} \\
\hline & & 1 & 2 & 3 & 4 & 5 & 6 & 7 & 8 & 9 & 10 \\
\hline 16. & Webinars & & & & & & & & & & \\
\hline 17. & $\begin{array}{l}\text { Courses Organized in } \\
\text { the Library }\end{array}$ & & & & & & & & & & \\
\hline 18. & Subject Guides & & & & & & & & & & \\
\hline 19. & $\begin{array}{l}\text { Feedback Tools about } \\
\text { Library Services }\end{array}$ & & & & & & & & & & \\
\hline \multirow[t]{2}{*}{20.} & $\begin{array}{l}\text { Tools That Allow } \\
\text { Communication } \\
\text { between Users }\end{array}$ & & & & & & & & & & \\
\hline & & 1 & 2 & 3 & 4 & 5 & 6 & 7 & 8 & 9 & 10 \\
\hline
\end{tabular}

- Q5. Please mark below whichever applies:

\begin{tabular}{|c|c|c|c|c|c|c|c|c|}
\hline \multicolumn{9}{|c|}{$\begin{array}{c}\text { TABLE } 4 \\
\text { Survey: Demographic Data }\end{array}$} \\
\hline \multicolumn{2}{|c|}{ Gender } & \multicolumn{5}{|c|}{ Age } & \multicolumn{2}{|c|}{ Research Area } \\
\hline Women & Men & $25-35$ & $36-45$ & $46-55$ & $56-65$ & $66+$ & Sciences & $\begin{array}{l}\text { Social } \\
\text { Sciences/ } \\
\text { Humanities }\end{array}$ \\
\hline & & & & & & & & \\
\hline
\end{tabular}

\section{Notes}

1. Differences in information behaviors and preferences found among the humanists and social scientists, contrasted with those typical of pure, life, engineering, and other sciences have been discussed by: George Buchanan et al., "Information Seeking by Humanities Scholars," eds. Andreas Rauber, Stavros Christodoulakis, and A Min Tjoa, Lecture Notes in Computer Science (Springer Berlin Heidelberg, 2005), 218-29; David Ellis, D. Cox, and K. Hall, "A Comparison of the Information Seeking Patterns of Researchers in the Physical and Social Sciences," Journal of Documentation 49, no. 4 (1993): 356-69; Jenny Fry, "Scholarly Research and Information Practices: A Domain Analytic Approach," Information Processing \& Management 42, no. 1 (2006): 299-316; Bradley M. Hemminger et al., "Information Seeking Behavior of Academic Scientists," Journal of the American Society for Information Science \& Technology 58, no. 14 (2007): 2205-25; Xi Niu et al., "National Study of Information Seeking Behavior of Academic Researchers in the United States," Journal of the American Society for Information Science \& Technology 61, no. 5 (2010): 869-90; Laura L. Haines et al., "Information-Seeking Behavior of Basic Science Researchers: Implications for Library Services," Journal of the Medical Library Association 98, no. 1 (2010): 73-81; Claire Warwick et al., "Library and Information Resources and Users of Digital Resources in the Humanities," Program: Electronic Library \& Information Systems 42, no. 1 (2008): 5-27; Sarah Robbins, Debra Engel, and Christina Kulp, "How Unique Are Our Users? Comparing Responses Regarding the Information-Seeking Habits of Engineering Faculty," College \& Research Libraries 72, no. 6 (2011): 515-32; Smiljana Antonijević and Ellysa Stern Cahoy, "Personal Library Curation: An Ethnographic Study of Scholars' Information Practices," portal: Libraries and the Academy 14, no. 2 (2014): 287-306.

2. Hemminger et al., "Information Seeking Behavior of Academic Scientists," 2205-25; Xi Niu et al., "National Study of Information Seeking Behavior," 869-90; Haines et al., "InformationSeeking Behavior of Basic Science Researchers," 73-81; Robbins, Engel, and Kulp, "How Unique Are Our Users?" 515-32.

3. Haines et al., "Information-Seeking Behavior of Basic Science Researchers," 73-81; Antonijević and Cahoy, "Personal Library Curation," 287-306. 


\section{Researchers' Expectations Regarding the Online Presence of Academic Libraries 949}

4. Stephann Makri et al., "Evaluating the Information Behaviour Methods: Formative Evaluations of Two Methods for Assessing the Functionality and Usability of Electronic Information Resources," International Journal of Human-Computer Studies 69, no. 7/8 (2011): 455-82.

5. Margaret Stieg Dalton and Laurie Charnigo, "Historians and Their Information Sources," College and Research Libraries 65, no. 8 (2004): 400-25; Buchanan et al., "Information Seeking by Humanities Scholars," 218-29; Donald W. King et al., "Scholarly Journal Information-Seeking and Reading Patterns of Faculty at Five US Universities," Learned Publishing 22, no. 2 (2009): 126-44; Carol Tenopir et al., "Variations in Article Seeking and Reading Patterns of Academics: What Makes a Difference?" Library \& Information Science Research (07408188) 31, no. 3 (2009): 139-48; Anna Mierzecka, " Information Behaviors within the Humanities: Searching or Browsing, Recall or Precision?" ZIN: Issues in Information Science, Information Studies 53, no. 1 (2015 ): 82-95.

6. Antonijević and Cahoy, "Personal Library Curation," 287-306.

7. Lotta Haglund and Per Olsson, "The Impact on University Libraries of Changes in Information Behavior among Academic Researchers: A Multiple Case Study," Journal of Academic Librarianship 34, no. 1 (2008): 52-59.

8. Sanna Talja and Hanni Maula, "Reasons for the Use and Non-Use of Electronic Journals and Databases," Journal of Documentation 59, no. 6 (2003): 673-91.

9. Carol Tenopir, Regina Mays, and Lei Wu, "Journal Article Growth and Reading Patterns," New Review of Information Networking 16, no. 1 (2011): 4-22; King et al., "Scholarly Journal Information-Seeking and Reading Patterns," 126-44; Tenopir et al., "Variations in Article Seeking and Reading Patterns of Academics," 139-48.

10. Antonijević and Cahoy, "Personal Library Curation," 287-306.

11. Pali U. Kuruppu and Anne Marie Gruber, "Understanding the Information Needs of Academic Scholars in Agricultural and Biological Sciences." Journal of Academic Librarianship 32, no. 6 (2006): 609-23.

12. Lynn S. Connaway, Timothy J. Dickey, and Marie L. Radford. “'If It Is Too Inconvenient I'm Not Going after It': Convenience as a Critical Factor in Information-Seeking Behaviors," Library $\mathcal{E}$ Information Science Research (07408188) 33, no. 3 (2011): 179-90; Yong-Mi Kim, “Why Should I Use University Library Website Resources? Discipline Differences," Journal of Academic Librarianship 37, no. 1 (2011): 9-18; Remigiusz Sapa, Monika Krakowska, and Malgorzata Janiak, "Information Seeking Behaviour of Mathematicians: Scientists and Students," Information Research 19, no. 4 (2014): 301-20.

13. Haglund and Olsson, "The Impact on University Libraries of Changes in Information Behavior," $52-59$.

14. Warwick et al., "Library and Information Resources," 5-27; E. Toms and Heather L. O'Brien, "Understanding the Information and Communication Technology Needs of the E-Humanist," Journal of Documentation 64, no. 1 (2008): 102-30.

15. Warwick et al., "Library and Information Resources," 5-27.

16. Niu et al., "National Study of Information Seeking Behavior," 869-90; Robbins, Engel, and Kulp, "How Unique Are Our Users?" 515-32.

17. Niu et al., "National Study of Information Seeking Behavior," 869-90; Bradley M. Hemminger et al., "Information Seeking Behavior of Academic Scientists," Journal of the American Society for Information Science \& Technology 58, no. 14 (2007): 2205-25.

18. Anabel Quan-Haase, Kim Martin, and Kathleen Schreurs, “Not All on the Same Page: E-Book Adoption and Technology Exploration by Seniors," Information Research-an International Electronic Journal 19, no. 2 (June 2014).

19. Connaway, Dickey, and Radford, "If It Is Too Inconvenient I'm Not Going after It," 179-90.

20. Makri et al., "Evaluating the Information Behaviour Methods," 455-82.

21. Haglund and Olsson, "The Impact on University Libraries of Changes in Information Behavior," $52-59$.

22. Connaway, Dickey, and Radford, "If It Is Too Inconvenient I'm Not Going after It," 179-90.

23. Kim, "Why Should I Use University Library Website Resources?" 9-18.

24. Toms and O'Brien, "Understanding the Information and Communication Technology Needs," 102-30; Haines et al., "Information-Seeking Behavior of Basic Science Researchers," 73-81; Connaway, Dickey, and Radford, “If It Is Too Inconvenient I'm Not Going after It," 179-90; David Seaman, "Discovering the Information Needs of Humanists When Planning an Institutional Repository," D-Lib Magazine 17, no. 3/4 (2011): 1; Antonijević and Cahoy, "Personal Library Curation," 287-306.

25. Haglund and Olsson, "The Impact on University Libraries of Changes in Information Behavior," 52-59; Antonijević and Cahoy, "Personal Library Curation," 287-306.

26. Remigiusz Sapa, Benchmarking W Doskonaleniu Serwisow WWW Bibliotek Akademickich (Kraków: Wydawnictwo Uniwersytetu Jagiellońskiego, 2005).

27. Anna Mierzecka and Andrius Suminas, "Academic Library Website Functions in the Con- 
text of Users' Information Needs," Journal of Librarianship and Information Science (first published online on Aug. 24, 2016): 1-11, doi:10.1177/0961000616664401.

28. Neither university provides access to demographic data of their faculty; that is why the authors were unable to discuss demographic characteristics of the respondents in that context.

29. Online resources not integrated with the website are understood as the links to useful Internet sites with valuable information neither created nor subscribed by library.

30. Robbins, Engel, and Kulp, "How Unique Are Our Users?" 515-32.

31. The question was not directly connected to respondents' academic libraries, although the prior experience may have influence; so it is worth noticing that Vilnius University Library uses Facebook, Twitter, and YouTube to promote its activity and the University of Warsaw Library uses Facebook.

32. Buchanan et al., "Information Seeking by Humanities Scholars,"218-29; Niu et al., "National Study of Information Seeking Behavior," 869-90; Hemminger et al., "Information Seeking Behavior of Academic Scientists," 2205-25; Haines et al., "Information-Seeking Behavior of Basic Science Researchers," 73-81; Makri et al., "Evaluating the Information Behaviour Methods," 455-82; Fry, "Scholarly Research and Information Practices," 299-316; Robbins, Engel, and Kulp, "How Unique Are Our Users?" 515-32; Antonijević and Cahoy, "Personal Library Curation," 287-306.

33. Antonijević and Cahoy, "Personal Library Curation," 287-306.

34. Haglund and Olsson, "The Impact on University Libraries of Changes in Information Behavior," $52-59$.

35. Antonijević and Cahoy, "Personal Library Curation," 287-306.

36. Connaway, Dickey, and Radford, “If It Is Too Inconvenient I'm Not Going after It," 179-90; Kim, "Why Should I Use University Library Website Resources?" 9-18.

37. Buchanan et al., "Information Seeking by Humanities Scholars," 218-29; Niu et al., "National Study of Information Seeking Behavior," 869-90; Hemminger et al., "Information Seeking Behavior of Academic Scientists," 2205-25; Haines et al., "Information-Seeking Behavior of Basic Science Researchers," 73-81; Makri et al., "Evaluating the Information Behaviour Methods," 455-82; Fry, "Scholarly Research and Information Practices," 299-316; Robbins, Engel, and Kulp, "How Unique Are Our Users?" 515-32; Antonijević and Cahoy, "Personal Library Curation," 287-306.

38. Dariah-EU is a pan-European infrastructure for arts and humanities scholars working with computational methods. For more, see: www.dariah.eu/about/dariah-in-a-nutshell.html.

39 DESMM (Digitally Enabled Scholarship with Medieval Manuscripts) is a Yale University project to introduce innovative tools for digital cultural heritage studies. For more, see: http:// ydc2.yale.edu/research-support/digitally-enabled-scholarship-medieval-manuscripts.

40. ATHENA, Automatic Text Height ExtractioN for the Analysis of old handwritten manuscripts, is a method to perform automatic text height estimation without the need of any kind of manual intervention and user-defined parameters, prepared by Yale's Computer Science Department. For more, see: http://ydc2.yale.edu/athena-automatic-text-height-extraction-analysis-oldhandwritten-manuscripts.

41. The results of the state evaluation of research institutions are one of the factors in determining the amount of the so-called statutory funding from the state budget, and publications in recognized academic journals are among the key elements of the assessment process. State evaluation was introduced in Poland in 2012 (see: Rozporządzenie Ministra Nauki I Szkolnictwa Wyższego z dnia 13 lipca 2012 r. w sprawie kryteriów i trybu przyznawania kategorii naukowej jednostkom naukowym", Dz.U. 2012 poz. 877, http://isap.sejm.gov.pl/DetailsServlet?id=WDU20120000877), and in 2010 in Lithuania (see: "Lietuvos Respublikos švietimo ir mokslo ministro issakymas Nr. V-1128, $2010 \mathrm{~m}$. liepos $10 \mathrm{~d}$.: Mokslo ir studijų institucijų mokslo (meno) darbų vertinimo metodika.").

42. See: Miroslaw Górny et al., "Mechanisms of the Formation and Evolution of Personal Information Spaces in the Humanities," Poznan: Wydawnictwo Rys, 2017; Anna Mierzecka, "Information Behaviors within the Humanities: Searching or Browsing, Recall or Precision?" ZIN: Issues in Information Science, Information Studies 53, no. 1 (2015): 82-95.

43. Carol Tenopir, "Trust in Reading, Citing and Publishing," Information Services \& Use 34 (2014): 39-48.

44. Haglund and Olsson, "The Impact on University Libraries of Changes in Information Behavior," 52-59; Yong-Mi Kim, "Why Should I Use University Library Website Resources? Discipline Differences," Journal of Academic Librarianship 37 (2011): 9-18.

45. Connaway, Dickey, and Radford, "If It Is Too Inconvenient I'm Not Going after It," 179-90; Hemminger et al., "Information Seeking Behavior of Academic Scientists," 2205-25; Niu et al. "National Study of Information Seeking Behavior," 869-90; Anabel Quan-Haase and Kim Martin, "Seeking Knowledge: An Exploratory Study of the Role of Social Networks in the Adoption of Ebooks by Historians," Proceedings of the American Society for Information Science and Technology 
48, no. 1 (2011): 1-10.

46. See: Cory Lown, Tito Sierra, and Josh Boyer, "How Users Search the Library from a Single Search Box," College \& Research Libraries 74, no. 3 (2013): 227-41; Aaron Tay and Yikang Feng, "Implementing a Bento-Style Search in Libguides V2," Code4Lib Journal, no. 29 (2015): 1.

47. Muhammad Tahir, Khalid Mahmood, and Farzana Shafique, "Use of Electronic Information Resources and Facilities by Humanities Scholars," Electronic Library 28, no. 1 (2010): 122-36; Andrew Johnson, Rebecca Kuglitsch, and Megan Bresnahan, "Using Participatory and Service Design to Identify Emerging Needs and Perceptions of Library Services among Science and Engineering Researchers Based at a Satellite Campus," Issues in Science \& Technology Librarianship, no. 81 (2015): 1.

48 Robbins, Engel, and Kulp, "How Unique Are Our Users?" 515-32.

49. Haines et al., "Information-Seeking Behavior of Basic Science Researchers," 73-81.

50. Kim, "Why Should I Use University Library Website Resources?" 9-18. 